\title{
Density functional theory study of the ethylene epoxidation over Ti-substituted silicalite (TS-1)
}

\author{
Jumras Limtrakul ${ }^{\mathrm{a}, 1}$, Chan Inntam ${ }^{\mathrm{a}}$, Thanh N. Truong ${ }^{\mathrm{b}, *}$ \\ ${ }^{a}$ Computational \& Applied Chemistry Laboratory, Physical Chemistry Division, Kasetsart University, Bangkok 10900, Thailand \\ ${ }^{\mathrm{b}}$ Department of Chemistry, Henry Eyring Center for Theoretical Chemistry, University of Utah, $315 \mathrm{~S} 1400 \mathrm{E}$, \\ Room 2020, Salt Lake City, UT 84112, USA
}

Received 2 January 2003; received in revised form 10 June 2003; accepted 10 June 2003

\begin{abstract}
The mechanism of ethylene epoxidation with hydrogen peroxide over Ti-substituted silicalite (TS-1) catalyst was investigated by using both the cluster and embedded cluster approaches at the B3LYP/6-31G(d) level of theory. The complete catalytic cycle was determined. The epoxidation of ethylene consists of three steps. First, the chemisorption of $\mathrm{H}_{2} \mathrm{O}_{2}$ at the Ti active site forms the oxygen donating Ti-OOH species and then the transfer of an oxygen atom from the Ti-OOH species to the adsorbed ethylene. The final step is the dehydration of the $\mathrm{Ti}-\mathrm{OH}$ species to regenerate to active center. The oxygen atom transfer step was found to be the rate-limiting step with the zero-point energy corrected barrier of $17.0 \mathrm{kcal} / \mathrm{mol}$ using the embedded cluster model at B3LYP/6-31G(d) level of theory, which is in agreement with the experimental estimate of about $16.7 \mathrm{kcal} / \mathrm{mol}$. Regeneration of the active center by dehydration of the Ti-OOH species was found to have a rather small barrier and the overall process is exothermic. Our results also show that inclusion of the effects of the zeolite crystal framework is crucial for obtaining quantitative energetic information. For instance, the Madelung potential increases the barrier of the oxygen atom transfer step by $5.0 \mathrm{kcal} / \mathrm{mol}$.
\end{abstract}

(C) 2003 Elsevier B.V. All rights reserved.

Keywords: Density functional theory; Ethylene epoxidation; Ti-substituted silicalite

\section{Introduction}

Ti-substituted silicalite (TS-1) has been widely used as a catalyst for several important oxidation reactions such as the olefin epoxidation, the phenol hydroxylation, cyclohexanone amoxidation, as well as the conversions of ammonia to hydroxylamine, of secondary alcohol to ketone, and of secondary amine to dialkylhydroxylamine [1-7]. In particular, its use in alkene epoxidation reactions with hydrogen peroxide as oxidant has been experimentally [4-7] and theoretically [8-15] studied. The characterization of TS-1 structure and the nature of its active site have been studied experimentally by using X-ray diffraction, IR, Raman, UV-Vis spectroscopy and EXAFS [16-21].

There have been several previous theoretical studies on the oxidation of ethylene over TS-1 catalysts using quan-

\footnotetext{
* Corresponding author.

E-mail addresses: fscijrl@ku.ac.th (J. Limtrakul), truong@chem.utah.edu (T.N. Truong).

${ }^{1}$ Co-corresponding author.
}

tum chemistry methods. These studies provided useful information on the mechanism and energetic properties of the reaction, though complete catalytic cycle has not been determined and the rate determining step has not been well understood. Furthermore, all of these studies used the cluster models to represent the reactive center and thus did not include the effects of the zeolite framework. In our previous study, we found that the Madelung potential from the zeolite framework can increase the adsorption energy of ethylene in H-ZSM-5 zeolite by about $50 \%$ and bring the predicted results in much closer agreement with experimental observations [22]. This indicates that the Madelung potential could be an important factor in stabilizing the adsorption complexes and transition states for the ethylene epoxidation over TS- 1 catalyst. To accurately include the effects of the extended zeolite framework on the catalytic properties, one can employ periodic electronic structure methods, such as the periodic density functional theory methodology. However, due to the large unit cells of typical zeolites, such calculations are often computationally demanding if it is still feasible. The embedded cluster methodology provides a cost 
effective computational strategy for including the effects of the zeolite framework [23-32]. In this approach, the effects of the zeolite framework can be modeled either by a classical molecular mechanic force field or by a set of point charges.

In this study, we investigated the complete catalytic cycle for the alkene oxidation over TS- 1 catalysts in the presence of hydroperoxides and the influence of a zeolitic framework, particularly the Madelung potential on the structural and energetic information. The surface charge representation of the external embedded potential (SCREEP) embedded cluster methodology was used. This method has been found to be rather accurate in representing the Madelung potential for studying adsorptions and reactions in zeolites [22,26-31].

\section{Method}

The active site of TS- 1 is modeled by a five-tetrahedral (5T) cluster $(\mathrm{OH})_{2} \mathrm{Ti}\left[\mathrm{OSi}(\mathrm{OH})_{2} \mathrm{OSiH}_{3}\right]_{2}$ selected from the ZSM-5 zeolite structure where the Ti atom is located at the T12 site. To have a more accurate description of the active site, $\mathrm{OH}$ terminations were used for $\mathrm{Si}$ atoms closed to the $\mathrm{Ti}$ atom. The T12 site has been used as an active site of ZSM-5 in many theoretical studies since it was predicted to be among the most stable Brønsted acid sites [33,34]. It is located at the intersection of main and sinusoidal channels and is accessible to adsorbates. It should be noted that the preferred Ti-substitution sites in TS-1 are still not known for certain and thus require further detailed study. The 5T cluster used in this study (see Fig. 1) is one half of the 10T ring and is the largest cluster that has been used previously. For the embedded cluster model, (see Fig. 1), this 5T cluster is embedded in a set of point charges according to the surface charge representation of external embedded potential method [23]. Accuracy of this method for modeling adsorption processes in zeolites has already been addressed in several previous studies [22,26-31]. These models consist of three layers. The center layer is a five-tetrahedral (5T) quantum chemical cluster. The next layer of the model is a set of explicit point charges located at the lattice positions. Their magnitudes were derived from periodic population analyses of zeolite systems. To minimize the interaction that occurs between the quantum mechanical terminating hydrogens and the neighboring point charges, the layer of explicit point charges nearest to the quantum cluster is moved out and combined with the next layer of point charges. The charge values of the moved point charges are fitted to minimize deviation from the original external electrostatic field. The outermost layer of the model is the SCREEP surface represented by a set of surface point charges to model the remaining Madelung potential from the extended zeolite crystal.

All geometry optimizations were done at the B3LYP/6$31 \mathrm{G}(\mathrm{d})$ level. The two $\mathrm{SiH}_{3}$ groups and $\mathrm{H}$ atoms of the six $\mathrm{OH}$ groups bonded to the $\mathrm{Ti}$ and $\mathrm{Si}$ atoms were fixed along the $\mathrm{Si}-\mathrm{O}$ crystal framework (see Fig. 2) while other atoms in the quantum cluster were allowed to relax in all geometry optimizations. Normal mode analyses were carried out to verify the transition states to have one imaginary frequency whose mode correspond to the designated reaction. All calculations were done using the Gaussian98 program [35].

\section{Results and discussion}

For the purpose of clarity, we separate the discussion below into two sub-sections. In one sub-section we discuss only the mechanisms of ethylene epoxidation by the TS-1 zeolite using the embedded cluster model. In the other section we focus only on the effects of the Madelung potential on structural and energetic information of this reaction by comparing the differences in the results predicted by the embedded and bare cluster models.

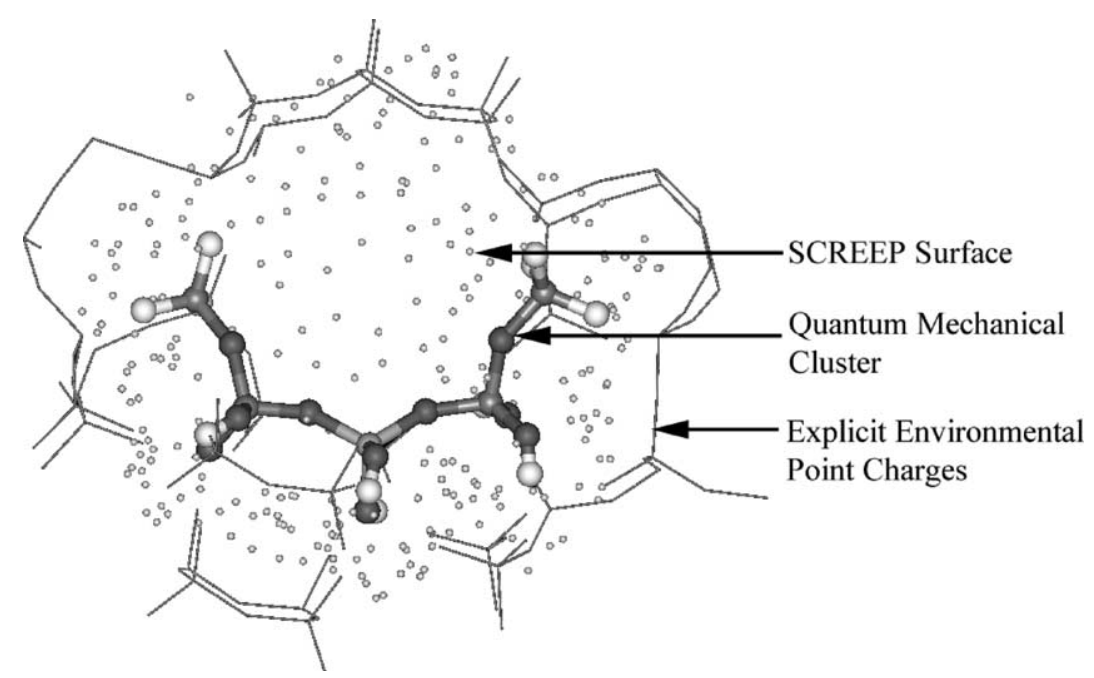

Fig. 1. SCREEP embedded cluster model for studying adsorption or reaction in zeolites. 


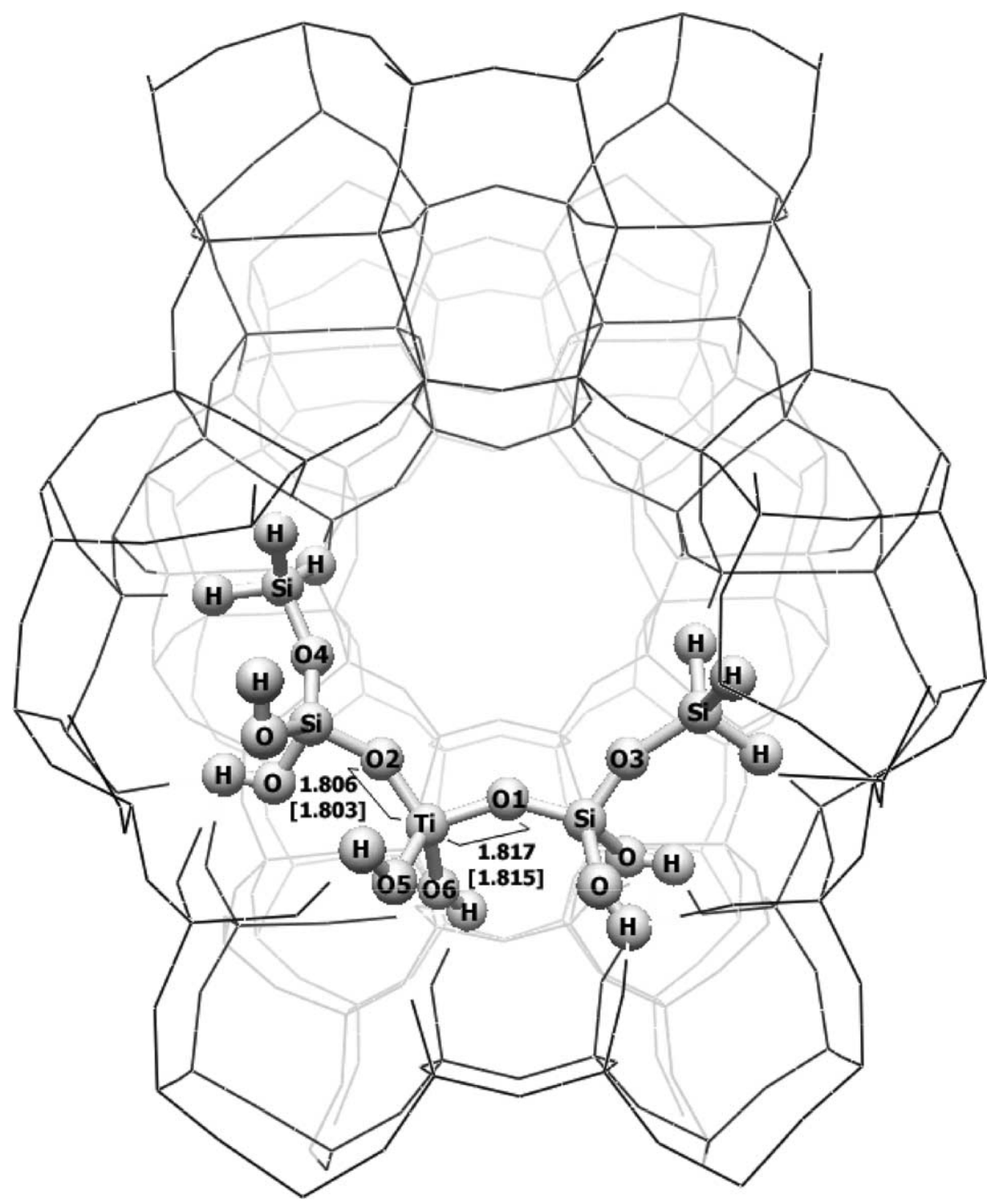

Fig. 2. Embedded 5T cluster model of the active site Ti(IV) of the TS-1 zeolite. Selected B3LYP/6-31G(d) optimized geometrical parameters using both the bare cluster and embedded cluster models are also given. The values in parentheses are obtained from the cluster model.

\subsection{Chemistry of ethylene epoxidation by TS-1 zeolite}

The complete catalytic cycle of the ethylene epoxidation by hydrogen peroxide is known to consist of three steps: (1) chemisorption of hydrogen peroxide to form $\mathrm{Ti}-\mathrm{OOH}$ active species; (2) epoxidation of ethylene by the Ti-OOH species and the desorption of the adsorbed ethylene epoxide; and (3) dehydration to regenerate the active center [8-15]. It is informative to first discuss the nature of the active site in comparison with known experimental data. This would provide indication on the accuracy of the computational method.

\subsubsection{The active site}

In this study, the active site of TS-1 is modeled by a Ti(IV) atom located at the T12 site of the ZSM-5 zeolite framework as shown in Fig. 2. Selected optimized geometrical parameters are reported in Table 1, and also depicted in Fig. 2.
Table 1

Selected optimized geometrical parameters of the active site of TS-1 using both the bare cluster and embedded cluster models at the B3LYP/6-31G(d) level of theory

\begin{tabular}{lccl}
\hline $\begin{array}{l}\text { Bond }(\AA) \text { or } \\
\text { angle }\left({ }^{\circ}\right)\end{array}$ & Embedded & Bare cluster & Expt. \\
\hline $\mathrm{Ti}-\mathrm{O} 1$ & 1.817 & 1.815 & - \\
$\mathrm{Ti}-\mathrm{O} 2$ & 1.806 & 1.803 & - \\
$\mathrm{Ti}-\mathrm{O} 5$ & 1.804 & 1.805 & - \\
$\mathrm{Ti}-\mathrm{O} 6$ & 1.766 & 1.790 & - \\
$\langle\mathrm{Ti}-\mathrm{O}\rangle$ & 1.798 & 1.803 & $1.79^{\mathrm{a}}, 1.80-1.81^{\mathrm{b}}$ \\
$\mathrm{Si}-\mathrm{O} 1$ & 1.630 & 1.642 & - \\
$\mathrm{Si}-\mathrm{O} 2$ & 1.633 & 1.646 & - \\
$\langle\mathrm{Si}-\mathrm{O}\rangle$ & 1.635 & 1.650 & - \\
$\angle \mathrm{Ti}-\mathrm{O} 1-\mathrm{Si}$ & 150.7 & 152.4 & \\
$\angle \mathrm{Ti}-\mathrm{O} 2-\mathrm{Si}$ & 140.6 & 144.7 & \\
$\angle \mathrm{O} 1-\mathrm{Ti}-\mathrm{O} 2$ & 108.3 & 110.5 & - \\
\hline
\end{tabular}

a XRD data is taken from [36].

b EXAFS data are taken from $[19,37,38]$. 
The calculated average Ti-O bond lengths of $1.798 \AA$ is in good agreement with that of $1.79 \AA$ obtained from XRD experiments [36] and of 1.80-1.81 $\pm 0.01 \AA$ from EXAFS $[19,37,38]$ experiments.

\subsubsection{Chemisorption of $\mathrm{H}_{2} \mathrm{O}_{2}$}

$\mathrm{H}_{2} \mathrm{O}_{2}$ chemisorbs on the Ti active site to form two possible active oxygen donor species, $\mathrm{Ti}-\mathrm{OOH}$ denoted as $\mathrm{Ti}\left(\eta_{1}-\mathrm{OOH}\right)$ and $\mathrm{Ti}\left(\eta_{2}-\mathrm{OOH}\right)$. In the former, the terminal oxygen atom of the $\mathrm{OOH}$ group binds to the $\mathrm{Ti}$ atom whereas in the latter both oxygen atoms of the $\mathrm{OOH}$ group bind to the Ti atom resembling a bidentate configuration.

The $\mathrm{Ti}\left(\eta_{2}-\mathrm{OOH}\right)$ species was found to be more stable than the $\mathrm{Ti}\left(\eta_{1}-\mathrm{OOH}\right)$ by about $9.2 \mathrm{kcal} / \mathrm{mol}$. This is slightly larger than that of $8.0 \mathrm{kcal} / \mathrm{mol}$ from the DFT/DNP done by Karlsen and Schoeffel [9]. For this reason, we focused only on the formation of the $\mathrm{Ti}\left(\eta_{2}-\mathrm{OOH}\right)$ species and its interaction with ethylene in the second step of the epoxidation process.

Fig. 3 shows structures of the stationary points for the dissociative chemisorption of $\mathrm{H}_{2} \mathrm{O}_{2}$ on the active site of TS-1 to form the Ti $\left(\eta_{2}-\mathrm{OOH}\right)$ species. Selected optimized geometrical parameters are listed in Table $2 . \mathrm{H}_{2} \mathrm{O}_{2}$ first molecularly adsorbs to the active site with the $\mathrm{O}_{a}$ atom binding to the $\mathrm{Ti}$ atom at the distance of $2.469 \AA$. The corresponding adsorption energies for the $\mathrm{H}_{2} \mathrm{O}_{2} / 5 \mathrm{~T}$ complex is $-10.8 \mathrm{kcal} / \mathrm{mol}$. This is lower than that of $-7.4 \mathrm{kcal} / \mathrm{mol}$ from non-local GGA/BP DFT single-point energy calculations at the optimized local LDA/VWN geometries done by Munakata et al. [15]. The difference is partly due to the inclusion of $\mathrm{H}$-bonding such as between $\mathrm{H}_{\mathrm{a}}-\mathrm{O}_{3}$ in our adsorbed complex (see Fig. 3a) but not in the model used by Munakata et al. [15].

The transition structure for chemisorption of $\mathrm{H}_{2} \mathrm{O}_{2}$ on TS-1 zeolite is shown in Fig. $3 \mathrm{~b}$. The chemisorption of the $\mathrm{H}_{2} \mathrm{O}_{2}$ molecule occurs over both the Ti and $\mathrm{O} 1$ atoms rather than just over the $\mathrm{Ti}$ atom. As the adsorption complex approaches the transition state the $\mathrm{Ti}-\mathrm{O}_{\mathrm{a}}$ bond is shortened from 2.469 to $2.151 \AA$, and the $\mathrm{H}_{\mathrm{a}}$ atom migrates to the $\mathrm{O} 1$ atom with the $\mathrm{O}_{\mathrm{a}}-\mathrm{H}_{\mathrm{a}}$ bond elongated from 0.976 to $1.249 \AA$. Due to the change in the valancy of the $\mathrm{O} 1$ atom as $\mathrm{H}_{\mathrm{a}}$ migrating over, the Ti-O1 bond distance is elongated from 1.826 to $2.043 \AA$. Continuing trends are observed as the system moves from the transition state to form the dissociated product, $\mathrm{Ti}\left(\eta_{2}-\mathrm{OOH}\right)$. Note that this complex plays a major role as an oxidizing agent in the oxidation reaction of unsaturated hydrocarbons. The optimized structure of $\mathrm{Ti}\left(\eta_{2}-\mathrm{OOH}\right)$ is in agreement with available experimental data [10] found in the crystal structure of $\left\{\left[\left(\eta_{2} \text {-tert-butylperoxo }\right) \text { titanatrane }\right]_{2} \cdot 3\right.$-dichrolomethane $\}$ $\mathrm{Ti}-\mathrm{O}_{\mathrm{a}}=1.97 \AA$ versus $1.91 \AA, \mathrm{Ti}-\mathrm{O}_{\mathrm{b}}=2.21 \AA$ versus $2.27 \AA$ and $\mathrm{O}_{\mathrm{a}-} \mathrm{O}_{\mathrm{b}}=1.48 \AA$ versus $1.47 \AA$ (the latter numbers are the experimental results).

The barrier height, $\Delta E_{\mathrm{a}}^{\mathrm{I}}$, for the chemisorption of $\mathrm{H}_{2} \mathrm{O}_{2}$ is predicted to be $13.6 \mathrm{kcal} / \mathrm{mol}$. Our finding is consistent with the previously reported barrier of $11.9 \mathrm{kcal} / \mathrm{mol} \mathrm{ob-}$
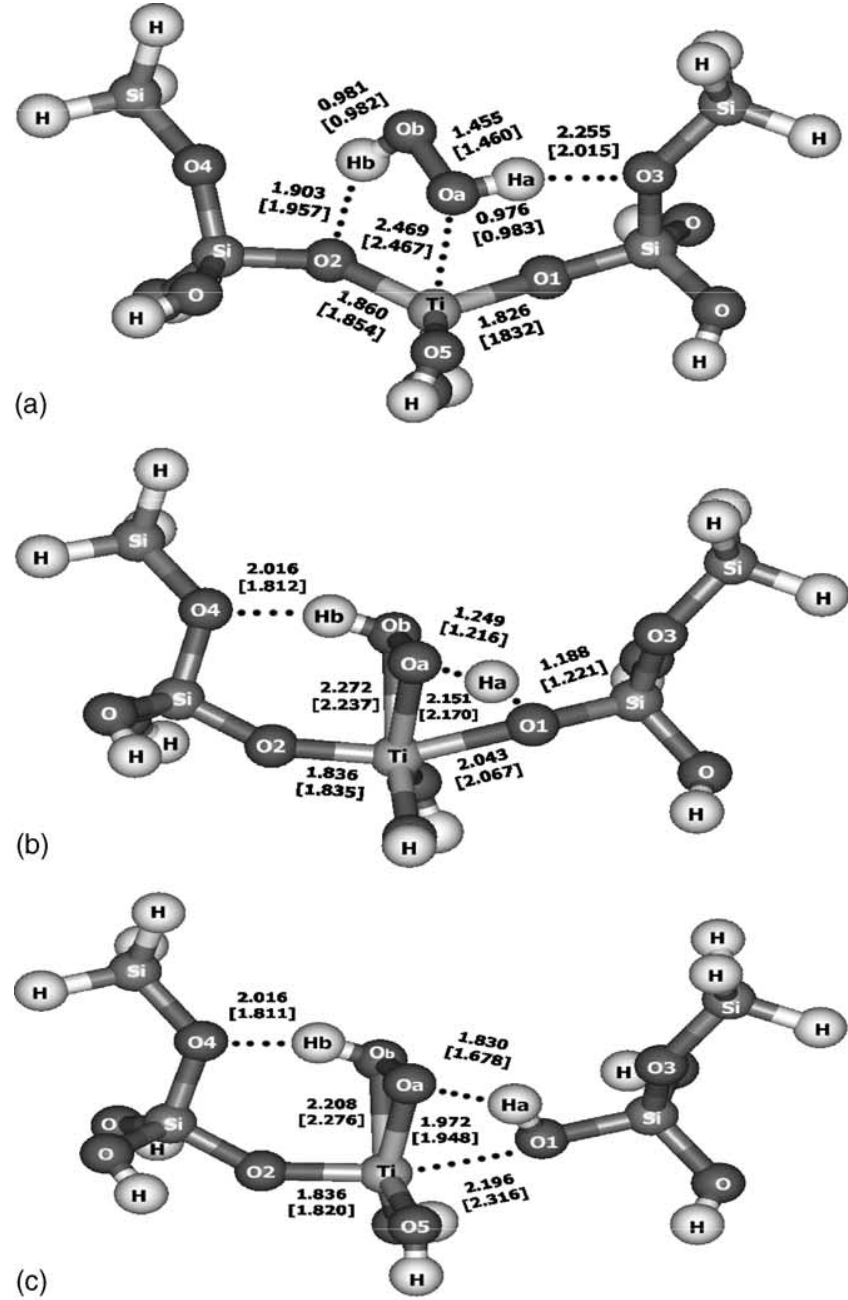

(c)

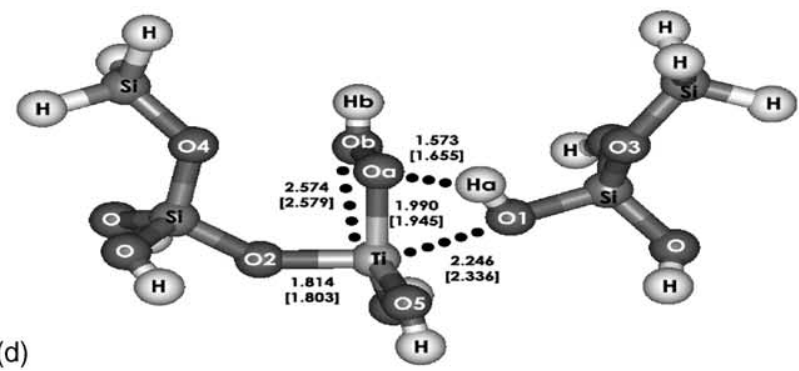

Fig. 3. Structures of the $\mathrm{H}_{2} \mathrm{O}_{2} / \mathrm{TS}-1$ complexes: (a) physisorbed complex; (b) transition state structure; (c) chemisorbed $\mathrm{Ti}\left(\eta_{2}-\mathrm{OOH}\right)$ complex; (d) chemisorbed Ti( $\left.\eta_{1}-\mathrm{OOH}\right)$ complex. Selected B3LYP/6-31G(d) optimized geometrical parameters using both the bare cluster and embedded cluster models are also given. The values in parentheses are obtained from the cluster model.

tained from BP86/DZVP calculations but with a smaller cluster [11]. The formation of $\mathrm{Ti}\left(\eta_{2}-\mathrm{OOH}\right)$ active species (Fig. 3c) is found to be energetically favorable with the reaction energy calculated to be $-3.2 \mathrm{kcal} / \mathrm{mol}$. Our predicted reaction energy is lower than that of Munakata et. al. [15] by $5.8 \mathrm{kcal} / \mathrm{mol}$ which may be due to the inclusion 
Table 2

Selected optimized geometrical parameters for the $\mathrm{H}_{2} \mathrm{O}_{2} / \mathrm{TS}-1$ system: (3a) physisorbed complex; (3b) transition state; (3c) chemisorbed product at the B3LYP/6-31G(d) level of theory

\begin{tabular}{|c|c|c|c|c|c|c|c|c|}
\hline \multirow{2}{*}{$\begin{array}{l}\text { Bond }(\AA) \text { or } \\
\text { angle }\left({ }^{\circ}\right)\end{array}$} & \multicolumn{2}{|c|}{ Physisorbed complex (Fig. 3a) } & \multicolumn{2}{|c|}{ Transition state (Fig. 3b) } & \multicolumn{2}{|c|}{$\mathrm{Ti}\left(\eta_{2}-\mathrm{OOH}\right)$ complex (Fig. 3c) } & \multicolumn{2}{|c|}{$\operatorname{Ti}\left(\eta_{1}-\mathrm{OOH}\right)$ complex (Fig. 3d) } \\
\hline & $\begin{array}{l}\text { Embedded } \\
\text { cluster }\end{array}$ & $\begin{array}{l}\text { Bare } \\
\text { cluster }\end{array}$ & $\begin{array}{l}\text { Embedded } \\
\text { cluster }\end{array}$ & $\begin{array}{l}\text { Bare } \\
\text { cluster }\end{array}$ & $\begin{array}{l}\text { Embedded } \\
\text { cluster }\end{array}$ & $\begin{array}{l}\text { Bare } \\
\text { cluster }\end{array}$ & $\begin{array}{l}\text { Embedded } \\
\text { cluster }\end{array}$ & $\begin{array}{l}\text { Bare } \\
\text { cluster }\end{array}$ \\
\hline Ti-O & 2.469 & 2.467 & 2.151 & 2.170 & 1.972 & 1.948 & 1.990 & 1.945 \\
\hline $\mathrm{Ti}-\mathrm{O}_{\mathrm{b}}$ & - & - & 2.272 & 2.237 & 2.208 & 2.276 & 2.574 & 2.579 \\
\hline Ti-O1 & 1.826 & 1.832 & 2.043 & 2.067 & 2.196 & 2.316 & 2.246 & 2.336 \\
\hline $\mathrm{Ti}-\mathrm{O} 2$ & 1.860 & 1.854 & 1.836 & 1.835 & 1.836 & 1.820 & 1.814 & 1.803 \\
\hline $\mathrm{O}_{\mathrm{a}}-\mathrm{O}_{\mathrm{b}}$ & 1.455 & 1.460 & 1.478 & 1.477 & 1.479 & 1.475 & 1.476 & 1.470 \\
\hline $\mathrm{O}_{\mathrm{b}}-\mathrm{H}_{\mathrm{b}}$ & 0.981 & 0.982 & 0.983 & 0.992 & 0.983 & 0.990 & 0.974 & 0.972 \\
\hline $\mathrm{O}_{\mathrm{a}}-\mathrm{H}_{\mathrm{a}}$ & 0.976 & 0.983 & 1.249 & 1.216 & 1.830 & 1.678 & 1.573 & 1.655 \\
\hline $\mathrm{O} 1-\mathrm{H}_{\mathrm{a}}$ & 2.543 & 2.495 & 1.188 & 1.222 & 0.987 & 0.999 & 1.015 & 1.000 \\
\hline $\mathrm{O} 3-\mathrm{H}_{\mathrm{a}}$ & 2.255 & 2.015 & - & - & - & - & - & - \\
\hline $\mathrm{O} 2-\mathrm{H}_{\mathrm{b}}$ & 1.903 & 1.957 & - & - & - & - & - & - \\
\hline $\mathrm{O} 4-\mathrm{H}_{\mathrm{b}}$ & 2.509 & 2.434 & 2.016 & 2.016 & 2.016 & 1.811 & 3.126 & 3.068 \\
\hline$\angle \mathrm{Ti}-\mathrm{O} 1-\mathrm{Si}$ & 157.3 & 155.1 & 138.9 & 154.9 & 137.0 & 177.5 & 171.8 & 178.4 \\
\hline$\angle \mathrm{Ti}-\mathrm{O} 2-\mathrm{Si}$ & 138.6 & 144.3 & 154.4 & 152.7 & 143.7 & 146.1 & 141.6 & 144.7 \\
\hline$\angle \mathrm{Ti}-\mathrm{O}_{\mathrm{a}}-\mathrm{O}_{\mathrm{b}}$ & 113.6 & 110.8 & 75.0 & 72.9 & 78.1 & 82.1 & 94.8 & 97.1 \\
\hline$\angle \mathrm{O} 1-\mathrm{Ti}-\mathrm{O} 2$ & 116.2 & 119.2 & 156.2 & 155.9 & 163.1 & 158.4 & 154.8 & 155.5 \\
\hline
\end{tabular}

of additional hydrogen bonding in our physical model, as mentioned earlier.

\subsubsection{Epoxidation of ethylene by $\mathrm{Ti}\left(\eta_{2}-\mathrm{OOH}\right)$ and desorption of ethylene epoxide}

Fig. 4 shows the structures of the oxygen atom transfer from the active $\operatorname{Ti}\left(\eta_{2}-\mathrm{OOH}\right)$ species to the absorbed ethylene and of the adsorbed product ethylene epoxide. Selected optimized geometrical parameters for these two stationary points are given in the figure and are also listed in Table 3. The ethylene molecule preferably attacks the $\mathrm{Ti}\left(\eta_{2}-\mathrm{OOH}\right)$ at the $\mathrm{O}_{\mathrm{a}}$ position yielding the product of ethylene epoxide

Table 3

Selected B3LYP/6-31G(d) optimized geometrical parameters for the $\mathrm{C}_{2} \mathrm{H}_{4}$ / $\operatorname{Ti}\left(\eta_{2}-\mathrm{OOH}\right)$ complexes

\begin{tabular}{|c|c|c|c|c|}
\hline \multirow[t]{2}{*}{$\begin{array}{l}\text { Bond }(\AA) \\
\text { or angle }\left({ }^{\circ}\right)\end{array}$} & \multicolumn{2}{|c|}{$\begin{array}{l}\text { Transition structure } \\
\text { (Fig. 5a) }\end{array}$} & \multicolumn{2}{|c|}{$\begin{array}{l}\text { Epoxide complex } \\
\text { (Fig. 5b) }\end{array}$} \\
\hline & $\begin{array}{l}\text { Embedded } \\
\text { cluster }\end{array}$ & $\begin{array}{l}\text { Bare } \\
\text { cluster }\end{array}$ & $\begin{array}{l}\text { Embedded } \\
\text { cluster }\end{array}$ & $\begin{array}{l}\text { Bare } \\
\text { cluster }\end{array}$ \\
\hline $\mathrm{Ti}-\mathrm{O}_{\mathrm{a}}$ & 2.037 & 2.053 & 2.314 & 2.461 \\
\hline $\mathrm{Ti}-\mathrm{O}_{\mathrm{b}}$ & 2.087 & 2.043 & 1.988 & 1.932 \\
\hline Ti-O1 & 2.323 & 2.333 & 2.327 & 2.341 \\
\hline $\mathrm{Ti}-\mathrm{O} 2$ & 1.830 & 1.818 & 1.818 & 1.815 \\
\hline $\mathrm{O}_{\mathrm{a}}-\mathrm{O}_{\mathrm{b}}$ & 1.791 & 1.807 & 2.636 & 2.622 \\
\hline $\mathrm{O}_{\mathrm{b}}-\mathrm{H}_{\mathrm{b}}$ & 0.974 & 0.979 & 0.970 & 0.972 \\
\hline $\mathrm{O} 4-\mathrm{H}_{\mathrm{b}}$ & 2.300 & 1.993 & 2.679 & 2.320 \\
\hline $\mathrm{O}_{\mathrm{b}}-\mathrm{H}_{\mathrm{a}}$ & 2.227 & 2.204 & 1.483 & 1.590 \\
\hline $\mathrm{O}_{\mathrm{a}}-\mathrm{H}_{\mathrm{a}}$ & 1.638 & 1.709 & 2.760 & 2.789 \\
\hline $\mathrm{O} 1-\mathrm{H}_{\mathrm{a}}$ & 1.005 & 0.997 & 1.038 & 1.013 \\
\hline $\mathrm{O}_{\mathrm{a}}-\mathrm{C} 1$ & 2.149 & 2.107 & 1.458 & 1.448 \\
\hline $\mathrm{O}_{\mathrm{a}}-\mathrm{C} 2$ & 2.265 & 2.152 & 1.458 & 1.450 \\
\hline $\mathrm{C} 1-\mathrm{C} 2$ & 1.355 & 1.358 & 1.467 & 1.466 \\
\hline$\angle \mathrm{Ti}-\mathrm{O} 1-\mathrm{Si}$ & 173.9 & 171.6 & 167.5 & 176.5 \\
\hline$\angle \mathrm{Ti}-\mathrm{O} 2-\mathrm{Si}$ & 144.0 & 142.8 & 142.6 & 143.1 \\
\hline$\angle \mathrm{Ti}-\mathrm{O}_{\mathrm{a}}-\mathrm{C}$ & 122.8 & 122.8 & 112.8 & 114.2 \\
\hline$\angle \mathrm{O} 1-\mathrm{Ti}-\mathrm{O} 2$ & 160.6 & 161.5 & 162.7 & 162.8 \\
\hline$\angle \mathrm{C} 1-\mathrm{Oa}-\mathrm{C} 2$ & 60.3 & 60.8 & 35.6 & 52.4 \\
\hline
\end{tabular}

(see Fig. 4a). A similar finding has also recently been reported [10]. At the transition state, the $\mathrm{Ti}-\mathrm{O}_{\mathrm{a}}$ distance (see Fig. 4a) is elongated from 1.972 to $2.037 \AA$. The C1-C2 distance is calculated to be $1.355 \AA$ which is only slightly larger than the corresponding $\mathrm{C}-\mathrm{C}$ distance of the isolated $\mathrm{C}_{2} \mathrm{H}_{4}$ (1.331 $\AA$ ) and is significantly smaller than that of the isolated epoxide $\mathrm{OC}_{2} \mathrm{H}_{4}$ species $(1.430 \AA)$. This indicates that the transition state is closer to the reactant than the product. Since the reaction is rather exothermic of $42.4 \mathrm{kcal} / \mathrm{mol}$, this result is consistent with the Hammond postulate (Table 4).

The barrier for the ethylene epoxidation, $\Delta E_{\mathrm{a}}^{\mathrm{II}}$, is predicted to be $18.5 \mathrm{kcal} / \mathrm{mol}$. As compared to the chemisorption of $\mathrm{H}_{2} \mathrm{O}_{2}$ step, the ethylene epoxidation is the rate-limiting step in this catalytic process. Including the zero-point energy correction lowers this barrier to $17.0 \mathrm{kcal} / \mathrm{mol}$. This result is particularly encouraging since it compares well with the experimental estimate for the activation barrier of $16.7 \mathrm{kcal} / \mathrm{mol}$ [39]. Fig. $4 \mathrm{~b}$ illustrates the product, $\mathrm{OC}_{2} \mathrm{H}_{4}$, adsorbed on the Ti-OH complex. We found that $\mathrm{O}-\mathrm{C} 1$ and $\mathrm{O}-\mathrm{C} 2$ distances of the $\mathrm{OC}_{2} \mathrm{H}_{4}$ molecule are virtually identical (1.448 $\AA$ versus $1.450 \AA$ ). These distances are slightly different from those of the isolate $\mathrm{OC}_{2} \mathrm{H}_{4}$

Table 4

Energies $(\mathrm{kcal} / \mathrm{mol})$ of stable complexes and transition states for the ethylene epoxidation reaction relative to the separated reactants

\begin{tabular}{lcc}
\hline & \multicolumn{2}{c}{ B3LYP/6-31G(d) } \\
\cline { 2 - 3 } & Embedded cluster & Bare cluster \\
\hline Physisorption complex (Fig. 3a) & -10.8 & -16.3 \\
Transition state I (Fig. 3b) & 2.8 & -4.7 \\
Ti( $\eta_{2}-$ OOH) complex (Fig. 3c) & -3.2 & -6.7 \\
Transition state II (Fig. 4a) & 15.3 & 6.8 \\
Epoxide complex (Fig. 4b) & -45.6 & -53.6 \\
Transition state III (Fig. 5b) & -41.6 & -46.2 \\
Water adsorption complex (Fig. 5c) & -67.6 & -64.5 \\
\hline
\end{tabular}



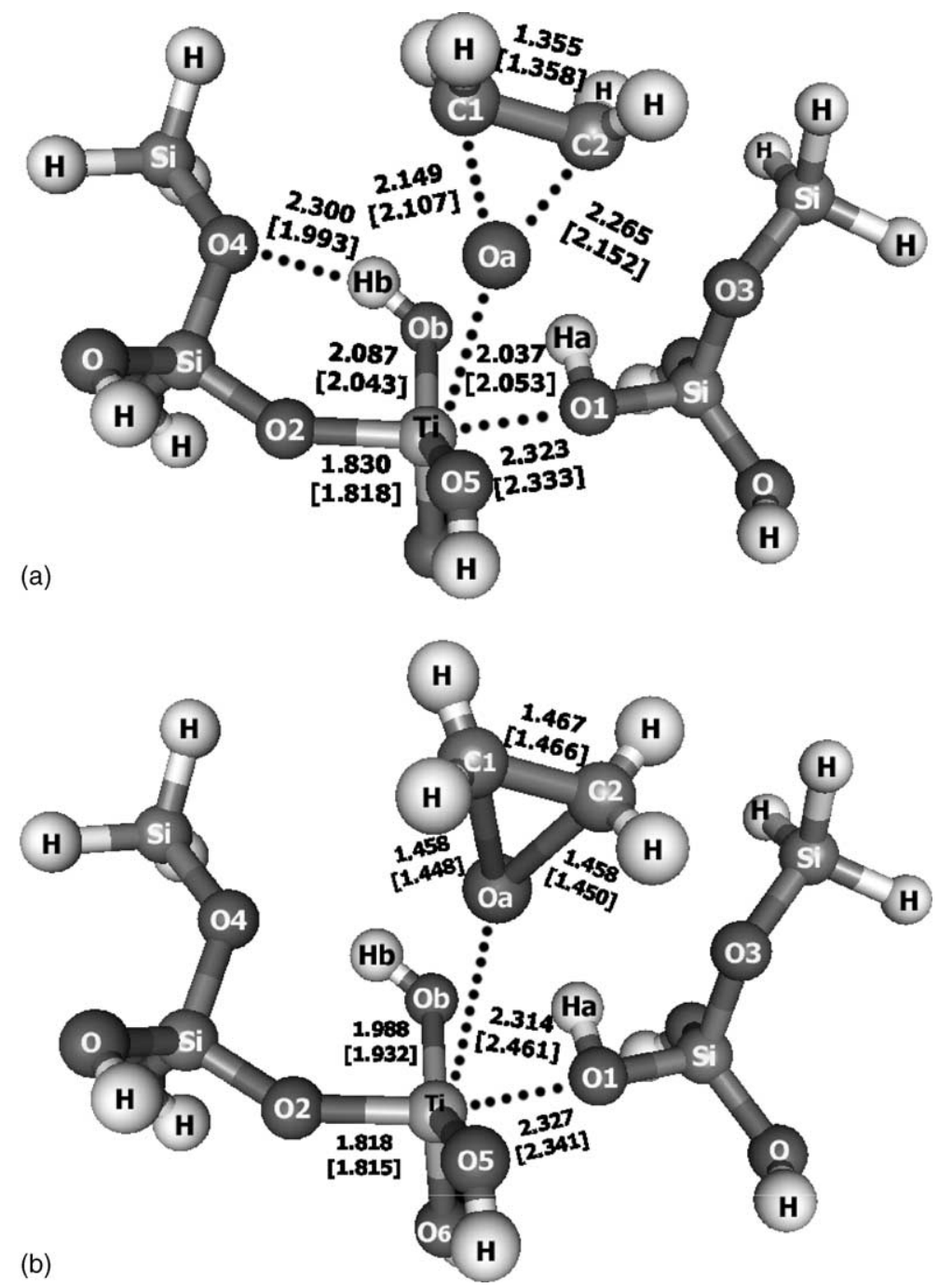

Fig. 4. Similar to Fig. 3, except for the geometries of (a) the transition state structure of the epoxidation step and (b) the adsorbed ethylene epoxide complex.

species, $\mathrm{C}-\mathrm{O}=1.431 \AA$ A. The reaction energy for formation of the $\mathrm{OC}_{2} \mathrm{H}_{4} / \mathrm{TiOH}$ complex is $-45.6 \mathrm{kcal} / \mathrm{mol}$ with respect to the separated reactants. In addition, we found that the calculated desorption energy of $\mathrm{OC}_{2} \mathrm{H}_{4}$ from the Ti-OH complex is predicted to be $3.3 \mathrm{kcal} / \mathrm{mol}$.

\subsubsection{Dehydration to regenerate the active site}

Previous studies have not considered the regeneration the active site by dehydration of the Ti-OH species. As shown in Fig. 5a-c, we found that this step involves the migration of a hydrogen atom $\mathrm{H} 1$ bound to the zeolite frame-work oxygen atom $\mathrm{O} 3$ to the oxygen of the $\mathrm{Ti}-\mathrm{OH}$ species and the strengthening of $\mathrm{Ti}-\mathrm{O} 3$ bond. In particular, the Ti-O2 from 1.903 to $2.266 \AA$. The concerted motion of the hydrogen migration and the shortening of the $\mathrm{Ti}-\mathrm{O} 3$ bond lead to a rather small barrier to dehydration step of $0.6 \mathrm{kcal} / \mathrm{mol}$ relative to the energy of the $\mathrm{Ti}-\mathrm{OH}$ species. The product of this step is the adsorbed water on the Ti active site. The step is also rather exothermic with the reaction energy of $-25.4 \mathrm{kcal} / \mathrm{mol}$ with respect to the $\mathrm{Ti}-\mathrm{OH}$ species. Desorp- tion of the adsorbed water to regenerate the Ti active site requires $21.1 \mathrm{kcal} / \mathrm{mol}$.

\subsubsection{Discussion}

Figs. 6 and 7 illustrate the catalytic cycle and schematic energy profile along this cycle with respect to the overall zero of energy, namely the energies of the separated reactants. It is clear that the rate-limiting step is the oxygen migration from the $\mathrm{Ti}-\mathrm{OOH}$ active species to the adsorbed ethylene. This step has the barrier of $15.3 \mathrm{kcal} / \mathrm{mol}$ relative to the overall zero and of $18.5 \mathrm{kcal} / \mathrm{mol}$ relative to the stable intermediate of adsorbed ethylene on the Ti-OOH species. The overall energy of the catalytic cycle is $-46.5 \mathrm{kcal} / \mathrm{mol}$. It is interesting to compare our present results with those from previous studies. Wu and Lai [8] reported a BLYP study using the $\mathrm{HOOTi}(\mathrm{OH})_{3}$ cluster model to study the epoxidation step and found the barrier height to be $10.7 \mathrm{kcal} / \mathrm{mol}$. Karlsen and Schoffel [9] used a rather small $\mathrm{Ti}(\mathrm{OH})_{4}$ cluster with the B88LYP/DNP method and found the corresponding barrier height to be $22.9 \mathrm{kcal} / \mathrm{mol}$. Hillier and co-workers 
(a)

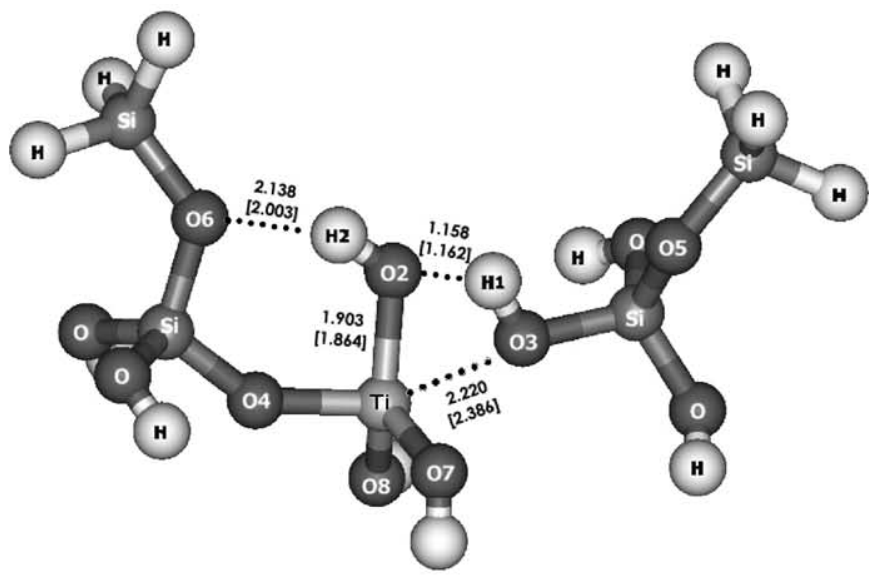

(b)
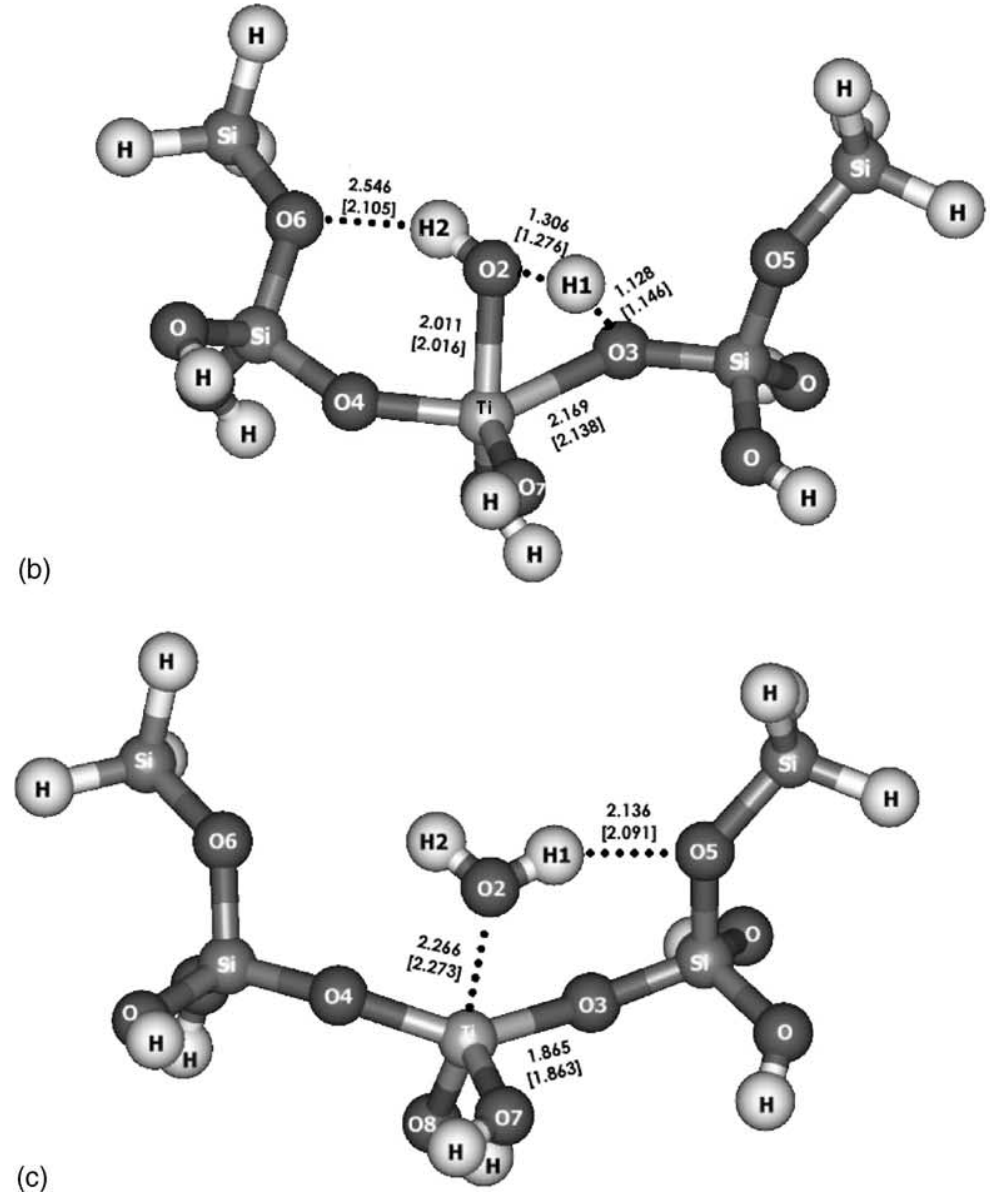

Fig. 5. Similar to Fig. 3, except for the optimized geometries of (a) the Ti-OH species; (b) the transition state for the dehydration step; and (c) the adsorbed water on the Ti active site.

[10] employed the B3LYP/3-21G(d) level of theory with the $\left(\mathrm{H}_{3} \mathrm{SO}\right)_{3} \mathrm{Ti}(\mathrm{IV})-\mathrm{O}(1) \mathrm{O}(2) \mathrm{H} / \mathrm{MeOH}$ cluster model and found that the corresponding barrier height was estimated to be $11.9 \mathrm{kcal} / \mathrm{mol}$. Using a different $4 \mathrm{~T}$ cluster model with the BP86 DFT method, Sinclair and Catlow [11] found that the chemisorption of $\mathrm{H}_{2} \mathrm{O}_{2}$ is the rate-limiting step instead of the epoxidation step with the barrier of $13.3 \mathrm{kcal} / \mathrm{mol}$ whereas the epoxidation step has a lower barrier of $10.2 \mathrm{kcal} / \mathrm{mol}$.
Munakata et al. [15] performed BP//VWN calculations with a different $5 \mathrm{~T}$ cluster to model the Ti active site. The authors modeled the epoxidation reaction with an additional water molecule in coordination with the adsorbates, $\mathrm{H}_{2} \mathrm{O}_{2}$ and $\mathrm{C}_{2} \mathrm{H}_{4}$ and found the barrier, relative to the complex [active site $\cdot \mathrm{H}_{2} \mathrm{O} \cdot \mathrm{C}_{2} \mathrm{H}_{4}$ ], is about $18.3 \mathrm{kcal} / \mathrm{mol}$. The estimated barrier of the epoxidation step is $15.8 \mathrm{kcal} / \mathrm{mol}$ with respect to the separated reactants. Our study does not consider such 


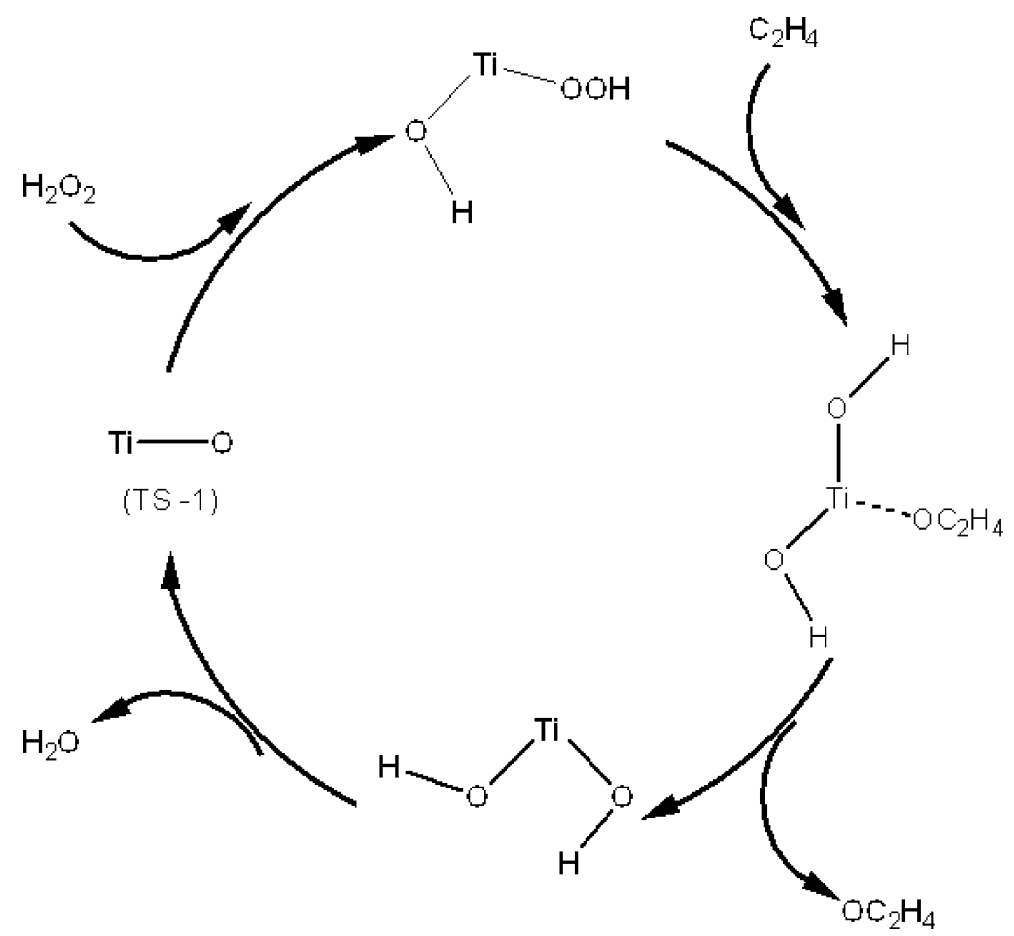

Fig. 6. Schematic diagram to illustrate the catalytic cycle for the epoxidation of ethylene by TS-1 zeolite.

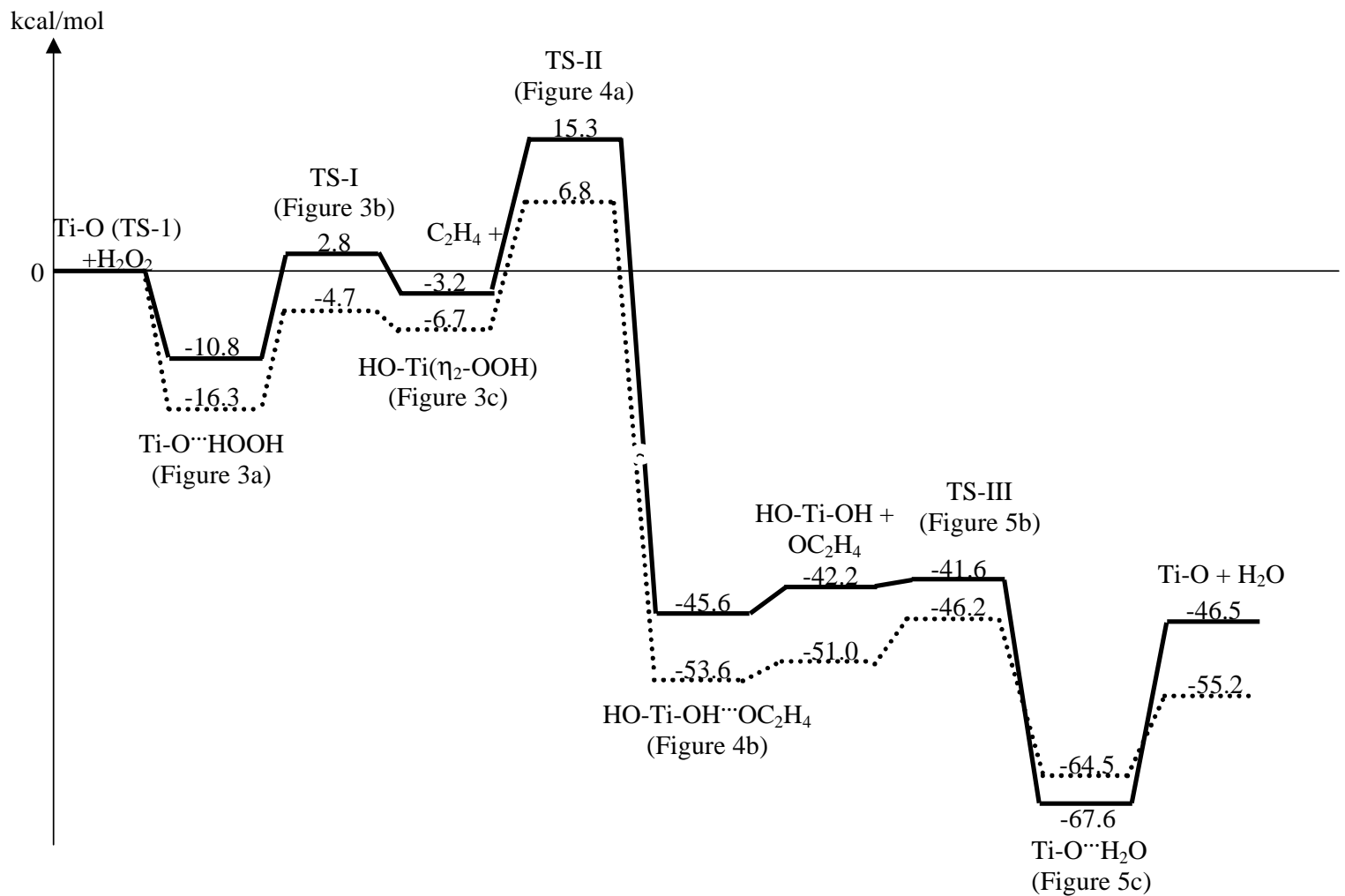

Fig. 7. Schematic energy profile for the epoxidation of ethylene by TS-1. Solid line is from the embedded cluster results and the dashed line is from the bare cluster results using the B3LYP/6-31G(d) level of theory. 
additional water and our results are also consistent with available experimental data. Thus, it is not clear what are the roles of the water in overall mechanism for the ethylene epoxidation by hydrogen peroxide in TS-1 zeolite. Though water is produced in the dehydration step with the adsorption energy of $-21.1 \mathrm{kcal} / \mathrm{mol}$ that is almost twice larger than the adsorption of the hydrogen peroxide on the $\mathrm{Ti}$ active site. However, the overall exothermicity of the catalytic cycle of $-46.5 \mathrm{kcal} / \mathrm{mol}$ would have sufficient energy to regenerate the active center. More study is certainly needed to further understand the roles of water in the mechanism of this reaction.

\subsection{Effects of the Madelung potential}

We found that the local structure of the active site of the TS-1 model is not very sensitive to the inclusion of the Madelung potentials. It is noted that the Madelung potential has an effect of destabilizing $\mathrm{Ti}\left(\eta_{1}-\mathrm{OOH}\right)$ and $\mathrm{Ti}\left(\eta_{2}-\mathrm{OOH}\right)$ by about $3.5 \mathrm{kcal} / \mathrm{mol}$ for the $\eta_{2}$ structure (Fig. 3c) and $2.1 \mathrm{kcal} / \mathrm{mol}$ for the $\eta_{1}$ structure (Fig. 3d) does not change the order of relative stability of the two complexes. The Madelung potential from the zeolite framework has a significant effect on the adsorption structure, particularly the hydrogen $\mathrm{H}_{\mathrm{b}}-\mathrm{O}_{2}$ and $\mathrm{H}_{\mathrm{a}}-\mathrm{O}_{3}$ bonds where it shortens the former by $0.05 \AA$ and elongates the latter by $0.3 \AA$. Consequently, it lowers the adsorption energy (or increases the binding energy) by $5.5 \mathrm{kcal} / \mathrm{mol}$. We found that the effects of the Madelung potential on the structure increase as the reaction proceeds toward the product. In fact at the dissociated product, $\mathrm{Ti}\left(\eta_{2}-\mathrm{OOH}\right)$ as shown in Fig. 3c, such effects were found to be noticeably large. The Ti-O1 bond is shortened by $0.12 \AA$ while $\mathrm{Ti}-\mathrm{O}_{\mathrm{a}}$ is elongated by $0.03 \AA$. For the transition state to oxygen migration step to form ethylene epoxide, the $\mathrm{Ti}-\mathrm{O}_{\mathrm{a}}$ bond distance is shortened by $0.16 \AA$. As a result, the Madelung potential increases the barrier for this rate-limiting step by $5.0 \mathrm{kcal} / \mathrm{mol}$. The largest effect of the Madelung potential is seen in the desorption energy of water to regenerate the $\mathrm{Ti}$ active site. It increases the water desorption energy by $11.8 \mathrm{kcal} / \mathrm{mol}$.

A general observation from these results and from the differences between our cluster and embedded cluster results is that the effects of the Madelung potential are rather large and thus the embedded cluster model used in this study appears to provide more quantitative information on the energetic properties as compared with experimental observation.

\section{Conclusion}

We have carried systematic ab initio cluster and embedded cluster studies on the mechanism of the ethylene epoxidation by hydrogen peroxide over the Ti-substituted silicalite zeolite. B3LYP/6-31G(d) level of theory was employed. The active site of the TS- 1 zeolite was modeled by a $5 \mathrm{~T}$ cluster. The effects of the Madelung potential from extended zeolite framework on the structural and energetic properties of this process were investigated. The complete catalytic cycle was determined. The reaction involves three steps: (a) the chemisorption of hydrogen peroxide to form $\mathrm{Ti}-\mathrm{OOH}$ active species; (b) the oxygen atom transfer from the $\mathrm{Ti}-\mathrm{OOH}$ active species to the adsorbed ethylene to form the produce ethylene peroxide and $\mathrm{Ti}-\mathrm{OH}$ species; and (c) the dehydration of $\mathrm{Ti}-\mathrm{OH}$ species to regenerate the $\mathrm{Ti}$ active site. The chemisorption of the $\mathrm{H}_{2} \mathrm{O}_{2}$ molecule on the TS-1 catalyst has the barrier of $13.6 \mathrm{kcal} / \mathrm{mol}$ to form dominantly oxygen donor species, $\mathrm{Ti}\left(\eta_{2}-\mathrm{OOH}\right)$ using the embedded cluster model. For the epoxide formation, the ethylene molecule interacts with the oxygen atom close to the Ti atom of the $\mathrm{Ti}\left(\eta_{2}-\mathrm{OOH}\right)$ complex. The epoxidation step is found to be the rate-limiting step where the oxygen atom from the Ti-OOH group transfer to the adsorbed ethylene molecule. The predicted activation energy including the zero-point energy correction for this step is $17.0 \mathrm{kcal} / \mathrm{mol}$. Our predicted results are in agreement with the experimental estimate for the activation barrier of $16.7 \mathrm{kcal} / \mathrm{mol}$. The dehydration of the $\mathrm{Ti}-\mathrm{OH}$ species to regenerate the Ti active site has rather small barrier. We found that the Madelung effects are rather large, in particular they increase the activation energy of the rate-limiting step by $5.0 \mathrm{kcal} / \mathrm{mol}$.

\section{Acknowledgements}

This work is supported by grants from the Thailand Research Fund (senior TRF research scholar), the Development and Promotion for Science and Technology Talents project (DPST), the Kasetsart University Research and Development Institute (KURDI) and the Ministry of University Affairs under the Science and Technology Higher Education Development Project (MUA-ADB funds). It is also supported in part by the ACS-PRF fund to TNT. The computer support from the University of Utah Center for High Performance Computing and Kasetsart 72 clusters is gratefully acknowledged. Our sincere thanks are due to Professor R. Ahlrichs (Karlsruhe, Germany) for his continued support of this work.

\section{References}

[1] M. Taramasso, G. Perego, B. Notari, U.S. Patent 4,410,501 (1983). [2] B. Notari, Adv. Catal. 41 (1996) 253.

[3] I.W.C.E. Arends, R.A. Sheldon, M. Wallau, U. Schuchardt, Angew. Chem. 36 (1997) 1144.

[4] M.G. Clerici, P. Ingallina, J. Catal. 140 (1993) 71.

[5] M.G. Clerici, G. Bellussi, U. Romano, J. Catal. 129 (1991) 159.

[6] C.B. Khouw, C.B. Dartt, J.A. Labinger, M.E. Davis, J. Catal. 149 (1994) 195.

[7] G. Bellussi, A. Catari, M. Clerici, G. Maddinelli, R. Millini, J. Catal. 133 (1992) 220.

[8] Y.D. Wu, D.K.M. Lai, J. Org. Chem. 60 (1995) 673.

[9] E. Karlsen, K. Schoffel, Catal. Today 32 (1996) 107. 
[10] D. Tantanak, M.A. Vincent, I.H. Hillier, Chem. Commun. (1998) 1031.

[11] P.E. Sinclair, C.R.A. Catlow, J. Phys. Chem. B 103 (1999) 1084.

[12] P.E. Sinclair, C.R.A. Catlow, Chem. Commun. (1997) 1881.

[13] M. Neurock, L.E. Manzer, Chem. Commun. (1996) 1133.

[14] G.N. Vayssilov, R.A. van Santen, J. Catal. 175 (1998) 170.

[15] H. Munakata, Y. Oumi, A. Miyamoto, J. Phys. Chem. B 105 (2001) 3493.

[16] G. Ricchiardi, A. Damin, S. Bordiga, C. Lamberti, G. Spano, F. Rivetti, A. Zecchina, J. Am. Chem. Soc. 123 (2001) 11409.

[17] J. Sudhakar Reddy, S. Sivasanker, P. Ratnasamy, J. Mol. Catal. 69 (1991) 383.

[18] T. Blasco, M.A. Camblor, A. Corma, J. Perez-Pariente, J. Am. Chem. Soc. 115 (1993) 11806.

[19] S. Bordiga, S. Collucia, C. Lamberti, L. Marchese, A. Zecchina, F. Boscherini, F. Buff, F. Genoni, G. Leofanti, G. Petrini, G. Vlaic, J. Phys. Chem. 98 (1994) 4125.

[20] F.J. Feher, D.A. Newman, J.F. Walzner, J. Am. Chem. Soc. 111 (1989) 1741.

[21] A. Zecchina, S. Bordiga, C. Lamberti, G. Ricchiardi, D. Scaranto, G. Petrini, G. Leofanti, M. Mantegazza, Catal. Today 32 (1996) 97.

[22] J. Limtrakul, T. Nanok, P. Khongpracha, S. Jungsuttiwong, T.N. Truong, Chem. Phys. Lett. 349 (2001) 161.

[23] E.V. Stefanovich, T.N. Truong, J. Phys. Chem. B 102 (1998) 3018.

[24] S.P. Greatbanks, I.H. Hillier, N.A. Burton, P. Sherwood, J. Chem. Phys. 105 (1996) 3370.

[25] R.Z. Khaliullin, A.T. Bell, V.B. Kazansky, J. Phys. Chem. A 105 (2001) 10454

[26] P. Treesukol, J. Limtrakul, T.N. Truong, J. Phys. Chem. B 105 (2001) 2421.

[27] J. Limtrakul, P. Khongpracha, S. Jungsuttiwong, T.N. Truong, J. Mol. Catal. A 153 (2000) 2469.

[28] S. Jungsuttiwong, S. Nokbin, P. Chuichay, P. Khongpracha, T.N. Truong, J. Limtrakul, Stud. Surf. Sci. Catal. 135 (2001) 2518.

[29] J. Limtrakul, P. Khongpracha, S. Jungsuttiwong, J. Mol. Struct. 525 (2000) 153

[30] J. Limtrakul, S. Nokbin, P. Chuichay, J. Mol. Struct. 560 (2001) 169.

[31] J. Limtrakul, S. Nokbin, S. Jungsuttiwong, P. Khongpracha, T.N. Truong, Stud. Surf. Sci. Catal. 135 (2001) 2469.
[32] (a) R. Vetrivel, C.R.A. Catlow, E.A. Colbourn, Proc. R. Soc. London A 417 (1998) 81;

(b) M. Allavena, K. Seiti, E. Kassab, G. Ferency, J.G. Angyan, Chem. Phys. Lett. 168 (1990) 461;

(c) G. Aloisi, P. Barnes, C.R.A. Catlow, R.A. Jackson, A.J. Richard, J. Phys. Chem. 93 (1990) 3573;

(d) J.C. White, A.C. Hess, J. Phys. Chem. 97 (1993) 8730;

(e) E.H. Teunisson, A.P.J. Jansen, R.A. van Santen, R. Orlando, R. Dovesi, J. Phys. Chem. 101 (1994) 5865;

(f) A. Kyrlidis, S.J. Cook, A.K. Chakraborty, A.T. Bell, D.N. Theodorou, J. Phys Chem. 99 (1995) 1505;

(g) E.H. Teunissen, A.P.J. Jansen, R.A. van Santen, J. Phys. Chem. 99 (1995) 1873;

(h) U. Eichler, M. Brandle, J. Sauer, J. Phys. Chem. B 99 (1997) 1873 ;

(i) M. Brandle, J. Sauer, J. Am. Chem. Soc. 120 (1998) 1556.

[33] E.G. Derouane, J.G. Fripat, Zeolites 5 (1985) 165.

[34] A.E. Alvaradoswaisgood, M.K. Baw, P.T. Hay, A. Redondo, J. Phys Chem. 95 (1991) 10031.

[35] M.J. Frisch, G.W. Trucks, H.B. Schlegel, G.E. Scuseria, M.A. Robb, J.R. Cheeseman, V.G. Zakrzewski, J.A. Montgomery, R.E. Stratmann, J.C. Burant, S. Dapprich, J.M. Millam, A.D. Daniels, K.N. Kudin, M.C. Strain, O. Farkas, J. Tomasi, V. Barone, M. Cossi, R. Cammi, B. Mennucci, C. Pomelli, C. Adamo, S. Clifford, J. Ochterski, G.A. Petersson, P.Y. Ayala, Q. Cui, K. Morokuma, P. Salvador, J.J. Dannenberg, D.K. Malick, A.D. Rabuck, K. Raghavachari, J.B. Foresman, J. Cioslowski, J.V. Ortiz, A.G. Baboul, B.B. Stefanov, G. Liu, A. Liashenko, P. Piskorz, I. Komaromi, R. Gomperts, R.L. Martin, D.J. Fox, T. Keith, M.A. Al-Laham, C.Y. Peng, A. Nanayakkara, M. Challacombe, P.M.W. Gill, B. Johnson, W. Chen, M.W. Wong, J.L. Andres, C. Gonzalez, M. Head-Gordon, E.S. Replogle, J.A. Pople, Gaussian'98, Gaussian, Inc., Pittsburgh, PA, 2001.

[36] G. Bellussi, V. Fatore, Stud. Surf. Sci. Catal. 69 (1991) 79.

[37] S. Pei, G.W. Zajak, J.A. Kaduck, J. Faber, B.I. Boyanov, D Duck, D. Fazzini, T.I. Morrison, D.S. Yang, Catal. Lett. 21 (1993) 333.

[38] R.J. Davis, Z. Liu, J.E. Tabora, W.S. Wielband, Catal. Lett. 34 (1995) 101.

[39] A. van der Pol, J.H.C. van Hooff, Appl. Catal. A 106 (1993) 97. 